\title{
Will you give birth in pain? Integrative review of obstetric violence in Brazilian public units
}

\author{
Parirás na dor? Revisão integrativa da violência obstétrica em unidades públicas brasileiras \\ Aline de Carvalho Martins ${ }^{1}$, Geiza Martins Barros²
}

DOI 10.5935/1806-0013.20160074

\section{ABSTRACT}

BACKGROUND AND OBJECTIVES: The study aimed at providing further visibility to discussions about obstetric violence suffered by Brazilian women in public health institutions. CONTENTS: This was an integrative review of the last decade, where 100 articles were evaluated to identify how Obstetric Violence is in Brazilian public health units.

CONCLUSION: Identified obstetric violences were: institutional violence, moral violence, physical violence, sexual violence, psychological and verbal violence.

Keywords: Healthcare personnel, Humanized delivery, Maternity, Women's rights, Violence against women.

\section{RESUMO}

JUSTIFICATIVA E OBJETIVOS: O estudo visou proporcionar maior visibilidade às discussóes acerca da violência obstétrica sofrida por mulheres brasileiras nas instituiçôes de saúde públicas.-

CONTEÚDO: Foi feita uma revisão integrativa da última década, onde foram analisados 100 artigos, para identificar como a Violência Obstétrica vem se apresentando nas unidades de saúde públicas brasileiras.

CONCLUSÁO: Os tipos de violências obstétricas identificadas foram: violência institucional, violência moral, violência física, violência sexual, violência psicológica e verbal.

Descritores: Direitos da mulher, Maternidade, Parto humanizado, Pessoal de saúde, Violência contra a mulher.

\footnotetext{
1. Fundação Oswaldo Cruz, Instituto Nacional da Saúde da Mulher, da Criança e do Adolescente Fernandes Figueira, Rio de Janeiro, RJ, Brasil.

2. Secretaria Municipal de Saúde, Hospital Municipal Miguel Couto, Rio de Janeiro, RJ, Brasil.

Submitted in July 11, 2016.

Accepted for publication in August 26, 2016.

Conflict of interests: none - Sponsoring sources: none.

Correspondence to:

Aline de Carvalho Martins

Instituto Nacional daSaúdedaMulher, daCriançaedoAdolescenteFernandes Figueira-Fiocruz. Av Rui Barbosa, 716 - Flamengo

22250-020 Rio de Janeiro, RJ, Brasil.

E-mail: rjalinemartins@yahoo.com.br

(C) Sociedade Brasileira para o Estudo da Dor
}

\section{INTRODUCTION}

With technological advances in healthcare, there is disqualification of popular knowledge and inconsideration of people's needs to favor scientific knowledge. Possibilities of horizontal dialogs and shared decisions between health professionals and users are submitted to technical knowledge and to the use of technology as synonym to qualified care. Positions such as these are being questioned by public policies, groups of professionals and users trying to expand the understanding of people's needs to beyond biological issues, reaffirming integrality, Single Health System (SUS) principles and citizenship as premises of good healthcare. These issues are more severe in social groups with poorer indicators and worse conditions to assert their rights. Within this discussion, there are issues involving violence against women. Implicit or explicit violence is been a common practice in healthcare units. Moments related to obstetric care (prenatal, delivery, abortion and puerperium) are more likely to suffer violence for being directly related to the female gender.

This is a model of attention which often removes women from the core of the issue and prevents their role as protagonists. It is denied that delivery, as well as gestation and birth, are physiological aspects to be understood by professionals involved with assistance to women and their families as a natural human life event. Pregnant women, in labor of common risk, look for a maternity to give birth to a baby and not to heal a disease. In many cases, as from the moment they access health institutions, women start to be seen as people needing multiple interventions for the birth to occur. If these issues go beyond delivery and women suffer abortion, especially provoked abortion, many times they have denied by healthcare services their right to be respected and admitted under the paradigm of right and integrality. In these cases, violence tends to be even more severe.

Women looking for obstetric care are exposed to different modalities of violence and disrespect to their bodies; be it by excessive manipulation, negligence with pain or verbal abuse. In public services this reality is even worse, because in Brazil, public healthcare services are related to poorer society segments.

These practices have been presented and questioned since the 1980s, through feminist movement struggles to assure women's rights through denunciations and discussions 
about institutional violence during delivery ${ }^{1}$ and abortion. Aiming at giving visibility to this issue, an integrative study was carried out to answer the following question: to which types of obstetric violence women are being submitted in Brazilian public units?

\section{CONTENTS}

A literature survey was carried out ${ }^{2}$ in March 2016, as from available studies in Virtual Health Library (BIREME) databases, chosen for the fact that it aggregates different national and international databases ${ }^{3}$. Inclusion criteria were publications between 2006 and 2016, directly addressing obstetric violence.

Based on the term "Obstetric Violence", 100 studies were selected to be part of this review. Texts came from LILACS, BDENF and Medline databases, in Portuguese and English. When the filter country/region was added to the term "Brasil", studies were reduced to 22. From these, nine were repeated and 13 were submitted to exclusion criteria for selection to this integrative review. Exclusion criteria were: studies addressing violence unrelated to obstetric issues and researches not linked to Brazilian public health units. Final sample was made up of five scientific articles: four articles and an unconventional study (video) ${ }^{4-8}$.

Selected studies were printed in full for data collection and the video was watched twice, being a tool to optimize analyzed information extraction. Studies were analyzed with an organized approach to weigh rigor and characteristics of each study, and then results were discussed and interpreted. An analytical category was developed and a summary of evidences found in the literature was prepared for readers to have the basis to critically evaluate presented results.

\section{Knowing the studies}

Obstetric violence is a recent subject among Brazilian academics. Although our study has limited the period to the last 10 years as temporal selection landmark, during search it was observed that there were no previous studies contemplating established inclusion criteria.

All texts dealing with obstetric violence in public health units referred to delivery and no article filtered by "obstetric violence" mentioned abortion, although this is a moment knowingly crossed by violence in Brazilian public health field, especially induced abortion. Literature seems to incorporate the difficulty present in social imagination, which identifies women inducing abortion as criminals, who should not be treated in equality of conditions of women who will have their babies and suffer violence.

It is worth mentioning that from five selected articles, 18 authors were identified making up eight different professional categories: pedagogy, psychology, law, biological sciences, obstetrics, social communication, nursing and medicine. From these, more than half of the studies were carried out by professionals graduated in nursing and medicine, being nursing responsible for $38.88 \%$ of total authorships. One may infer that health professionals more directly related to assistance to women in labor, delivery and immediate post-delivery (nursing and medicine) are those who have lectured more about the subject of this study. However, it is worth stressing that there are other professional categories involved in obstetric assistance, especially if women's approach is based on the paradigm of integrality. Violence is multifactorial and, as such, needs articulation and interaction of different professional categories to be coped with.

Another highlight is the issue of gender involving obstetric violence, because in addition to being suffered by women, often violence is also practiced by female professionals, because they represent the majority of professionals working in healthcare units assisting pregnant and puerperal women, thus the importance of discussing power actions which permeate the relationship between professionals and SUS users, as well as their attention models. No study had a male as coauthor, which shows the distance of males from this discussion. In fact, delivery happens in women's body and violence in this space seems to be socially seen as women's problem.

A positive characteristic was the collective nature of such discussions. It seems to be a positive indicator that this discussion is mobilizing groups of people, thus revealing broader amplitude of the subject in healthcare services.

It calls the attention that this is an issue of workers' daily activities and thought by them, showing awareness and interest of professionals in fighting violence. Studies are based on literature review ${ }^{4}$, on professional experiences,7 and on the voice of women themselves ${ }^{6,8}$. Although undeniable the pertinence of studies and the commitment of involved professionals, the fact that more than half the studies do not directly analyze subjects suffering violence, shows the need for studies trying to give voice to these women and with this also assuring them autonomy and protagonism in fighting this type of violation of rights.

This process might be happening because the obstetric violence theme is not always recognized by women themselves. The issue is pegged to demands of professionals who are able to recognize obstetric violence in their daily activities. Although identifying mobilizations in communication media, promoted by the feminist movement, professionals, academy and also by women themselves to make these obstetric violence practices to be identified and overcome, this is still an early movement.

General scenario of analyzed studies:

\section{Types of obstetric violence pointed by the literature}

Studies show that obstetric violence does not equally reach all subjects. Poor ${ }^{4,7}$, black $^{7}$, with lower education ${ }^{7,8}$, complainant or poorly cooperative ${ }^{6,7}$ women and without access to essential health services, including prenatal ${ }^{4}$, are more exposed to violent behaviors of health professionals. Not all studies have categorized or grouped these types of 
violence. However, we considered important to categorize types of violence, because it is necessary to give visibility to the issue and categorization might be an important tool for didactic purposes. Based on the literature, the following categories were identified: institutional violence, moral violence, physical violence, sexual violence, psychological and verbal violence.

These issues are not always clear and visible in the services. Very often, not even professionals are able to identify certain behaviors as violent (or do not want to recognize them as such). The use of violent approaches by health professionals is often presented and advocated as a necessary care to deal with women considered complainant, demanding or poorly cooperative ${ }^{7}$. In this context, violence is disguised as best practice, since allegedly its highest interest would be patients' wellbeing ${ }^{7}$. This is a strategy to assure institutional invisibility to violence ${ }^{7}$.

In SUS, obstetric violence starts in the institutional level. Literature points as institutional violence: lack of access of poor women to essential services ${ }^{4}$ and women's peregrination to different maternities to get assistance. When health assistance is assured, women may be faced with lack of adequate structure, precarious physical and human resources, being victims of institutional processes which are often unable to assure the presence of an anesthesiologist on duty to induce labor analgesia ${ }^{7}$, the prohibition of escorts during delivery, although this is a right assured by law 11.108 of $2005^{6}$, or prohibition of men in the pre-delivery room, on the grounds of lack of physical space assuring privacy to other patients ${ }^{7}$, or lack of conditions for private care ${ }^{4}$.

If the institutional space is violator of rights, unnecessary procedures carried out by professionals and without scientific evidences of benefits will tend to worsen this situation. Delivery moment is especially seen as violator of rights. In this period, women are particularly exposed to moral violence.

Moral violence is the violence less linked to institutional standards, physical spaces and equipment and more associated to professional approaches. Examples of this violence are: not recognizing women as subjects of the delivery ${ }^{5,6}$ and placing the physician on their place, giving him authority, responsibility and active conduction of this process $^{5}$, controlling and having ownership of the event ${ }^{5}$, reinforcing birth not as a physiological experience but rather as an event with imminent risks ${ }^{6}$.

This process depreciates autonomy and understanding of parturients about their body ${ }^{7}$, overestimates the use of technology 5,6 and directs the system toward profits ${ }^{5}$. The appreciation of techniques and interventions as a value by themselves is reflected in excessive medication, in the assistance to labor and delivery, especially for low risk pregnant women and their babies 5 and in the use of technical jargon, unintelligible for patients, thus reinforcing the system of dominating and subjecting these women ${ }^{8}$.

For this reason, women are alienated ${ }^{5}$, depersonalized ${ }^{4,8}$, dehumanized $^{3}$, annulled in their identities ${ }^{4}$ and trans- formed in a hospital chart number, in a case to be studied, diagnosed and treated ${ }^{4}$, the most common consequences of which are breach of confidentiality and privacy invasion ${ }^{4,7}$. Discriminative and inhuman attitudes in delivery assistance based on differences of class, gender and race $e^{4,6,7}$, will cause women to be chosen for the training of procedures such as episiotomy, forceps or Cesarean sections, according to their hierarchical order of social value ${ }^{4}$.

For those with less social recognition, there are moral violence practices such as abandon, disrespect, negligence with their pain or assistance refusal ${ }^{4,6,7}$, prohibition of expressing themselves ${ }^{4,6}$ and retaliations or veiled mistreatments when demanding their rights, asking for certain services ${ }^{4,6}$ or are considered complainant ${ }^{4,6,7}$. Studies have observed that employees had aggressive and intimidating postures ${ }^{4}$ with this group of women.

As physical violence there were primarily inadequate use of technology during delivery ${ }^{5}$ : lythotomy (unfavorable position for birth), Kristeller maneuver, violent or excessive touches ${ }^{5,6}$, episiotomy for training purposes ${ }^{4-6}$, amniotomy, use of synthetic ocytoxin ${ }^{5,6}$ and denial of analgesia ${ }^{6}$. Physical violence is also the receipt of authorization for interventions based on partial or distorted information, such as lying to patients about dilatation or fetal vitality, forging indications which are not real, such as fetal macrossomy, meconium, nuchal cord, narrow maternal pelvis to indicate Cesarean section due to personal interests ${ }^{4,5}$, denial of information about patients conditions and labor evolution and women's manipulation without previous explanation of procedures ${ }^{3,6-8}$ or even performing procedures without women's consent ${ }^{4}$.

Sexual violence is not often reported in the literature. Excessive touches and episiotomy appear in the literature as recurrent labor issues, but without direct link with sexual violence. References to sexual violence present in the literature are coercive and moralist statements with sexual content at delivery time . $^{7}$.

Psychological and verbal violence: associated to this type of violence are comments used to denigrate women and deny the recognition of their specific state during labor. It was also identified the non recognition as legitimate of situations in which external environment and women's emotional status act impairing labor and delivery ${ }^{5}$, women's judgment and culpability ${ }^{6}$, name calling, hostilities and shouts $^{7,8}$, verbal abuse, humiliation of pregnant women ${ }^{4}$, ironic words or expressions $s^{5,7}$, unrespectful comments ${ }^{6-8}$, reprimands and abandonment threats ${ }^{7,8}$.

\section{CONCLUSION}

Institutions are involved in coping with this subject and should give visibility to the issue of violation of rights, taking responsibility for its eradication, for the development of institutional protocols based on scientific evidences, for professional training, for human resources and available materials. 


\section{REFERENCES}

1. Venturi Jr G, Aguiar JM, Hotimsky SN. A violência institucional no parto em maternidades brasileiras: uma análise preliminar de dados da pesquisa de opiniâo pública Mulheres Brasileiras e Gênero nos Espaços Público e Privado - 2010. Trabalho apresentado em VII Congresso Brasileiro de Enfermagem Obstétrica e Neonatal (COBEON), Belo Horizonte, ABENFO-MG, 2011. Disponível em http://www.redesindical. com.br/abenfo/viicobeon_icieon/mesas/13_02.pdf. Acesso em 22 de abril de 2016.

2. Souza MT, Silva MD, Raquel C. Revisão integrativa: o que é e como fazer. Einstein. 2010;8(1 Pt 1):102-6.

3. Guia da BVS 2011. / BIREME / OPAS / OMS (org.). São Paulo: BIREME / OPAS / OMS, Março 2011

4. Diniz SG, Salgado HO, Andrezzo HF, Carvalho PG, Carvalho PC, Aguiar CA, et al.
Violência obstétrica como questâo para a saúde pública no Brasil: origens, definiçóes, tipologia, impactos sobre a saúde materna, e propostas para sua prevenção. Rev Bras Crescimento Desenvolv Hum. 2015;25(3):377-84

5. Sanfelice CF, Abbud FS, Pregnolatto OS, Silva MG, Shimo AK. Do parto institucionalizado ao parto domiciliar. Rev Rene. 2014;15(2):362-70.

6. Oliveira GD. Nascer no Brasil: o retrato do nascimento na voz das mulheres. RECIIS - Rev. Eletron Comun Inf Inov Saúde. 2015 abr.-jun.; 9(2) |www.reciis.icict.fiocruz.br] e-ISSN 1981-6278. Disponível em: https://www.youtube.com/watch?v=Q9G5uyRKsykacesso em 21 de março de 2016. Acesso em 20 de abril de 2016.

7. Aguiar JM. d'Oliveira AF. Schraiber LB. [Institutional violence, medical authority, and power relations in maternity hospitals from the perspective of healthy workers]. Cad Saude Publica, 2013;29(11):2287-96. Portuguese.

8. Teixeira NZ, Pereira WR. [Hospital delivery--women's experience from the suburbs of Cuiabá-MT]. Rev Bras Enferm. 2006;59(6):740-4. Portuguese. 